\title{
CLEAN ENERGY GENERATION USING GROUNDNUT OIL MILL EFFLUENT WITH MICROBIAL FUEL-CELL
}

\author{
S. M. Lawan ${ }^{1, *}$, I. Abba ${ }^{2}$, B. D. Bala ${ }^{3}$, A. Y. Abdullahi' ${ }^{4}$ and A. Aminu ${ }^{5}$

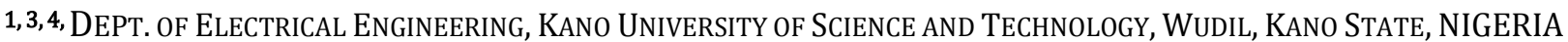 \\ 2,5, Dept. of Electrical EngineERing, Kano State Polytechnic, Matan Fada Road, Kano, Kano State, Nigeria \\ Email addresses.13alisumuhdlawan@gmail.com, 2ibrahimaaba@yahoo.com,3bdbla2@gmail.com, \\ 4ayayusuf234@gmail.com, 5 ahmadkksr@gmail.com
}

\begin{abstract}
Microbial system that converts organic matter to energy is proposed in this paper. An attempt is made, to examine the potential of using groundnut oil mill effluent (GOME) as substrates to Microbial Fuel Cell (MFC). A methodology was developed to obtain a power density in batches by varying the feed rate of continuous flow in the MFC. The results obtained show that GOME produces higher energy per unit area compared to other mixed culture reported in scientific literatures. The minimum and maximum power densities obtained are $160 \mathrm{~mW} / \mathrm{m}^{2}$ and $217 \mathrm{~mW} / \mathrm{m}^{2}$ at low feed rate of ( 400 litre/hr) with cell potential of $625 \mathrm{mV}$ and high feed rate of (420 litre $/ \mathrm{hr}$ ) with cell potential $727 \mathrm{mV}$ respectively. Furthermore, the findings of this research work showed that MFC could produce higher power density at continuous flow process mode $\left(160 \mathrm{~mW} / \mathrm{m}^{2}\right)$ compared to batch process $\left(54 \mathrm{~mW} / \mathrm{m}^{2}\right)$. Thus, this study demonstrates the potential of generating clean energy via GOME, with by-products of carbon dioxide and water.
\end{abstract}

\section{Keywords: Clean energy, Fossil-fuel, Renewable energy, Fuel-cell, Groundnut Oil Mill Effluent (GOME)}

\section{INTRODUCTION}

It is acknowledged that fossil fuel is a finite source of energy, and contributes in increasing carbon emission at the lower layer of the atmosphere. The negative effects of fossil fuels have been the major concerned around the world. It is believed that using the conventional sources (petroleum, coal and gas) is a serious problem that is affecting our environments. Owing to those effects, several countries around the world have signed the deal of reducing carbon level to certain levels, at the same time most of those countries have also agreed to encourage the usage of renewable energy $[1,2]$. Renewable energy is naturally abundant, but the availability varies depending on the locations. Nigeria government has endorsed power generation via renewable energy sources such as wind, hydro, tidal, geothermal, solar and biomass. Groundnut which is sometimes called Peanut has a botanical name of Arachis hypogaea. It is one of the major crops grown in Nigeria especially in the northern part either for its nut, oil or its stem. Groundnut is mainly grown in the northern part of Nigeria, in large quantities compared to other regions of the country. The below-listed states account for about $83-88 \%$ of the production, and they are; Kano, Kaduna, Taraba, Bauchi, Bornu, and Adamawa [3, 4].

The groundnut oil effluent is very high in content of degradable organic matter. The effluent is polluting if left untreated and channel to the water course. Therefore, it is good to treat the effluent to reduce the pollution effects. This can be achieved under anaerobic condition that produces methane gas, which is popularly known as biogas. When this gas is emitted to the environment, it will affect the environment an increase the rate of global warming. Because of the environmental worries, this gas should be harnessed rather than to be released to the environment. Biomass sector is one of the areas that will be utilised to harness the energy for micro and small applications $[5,6]$.

Fuel cell is one of the potential renewable energy sources around the globe. It is a system that oxidises or reduces chemical to produce electric current. It contains two electrodes called Anode and Cathode. These electrodes are separate by electrolyte or membrane. Chemically available, a fuel cell takes in hydrogen and air to produce water and heat. According to the recent review on fuel cell, there are different types of fuel cells namely Alkaline Fuel Cell (AFC), Proton Exchange Fuel Cell (PEF), Direct Methanol Fuel 
Cell (DMFC), Phosphoric Acid Fuel Cell (PAF), Molten Carbonate Fuel Cell (MCF), Solid Oxide Fuel Cell (SOFC) and Microbial Fuel Cell (MFC), AFC is commercially, while the rest are being developed $[7,8]$.

MFC is considered as a promising new technology for the efficient production of electrical energy via waste treatment. It is a device that uses bacteria as catalysts to oxidize organic and inorganic matter to generate electrical current. The electron will flow from anode to cathode chamber via proton exchange membrane. The advantage of using MFC over other fuel cells is the capability of MFC to convert chemical energy into useful electrical energy [9].

Several researchers have demonstrated the potential of using high quality and reliable substrate for MFC, some of the waste that had been used as MFC substrates are domestic water [10], anaerobic sediments [11], swine waste water [12], meat packing waste water [13] and animal waste water [14]. Detailed study on different materials and methods used to construct MFCs, can be found in [15].

In terms of MFC reactor design, many research works are on-going. Among the recent studies conducted, Korneel and Verstraete [16] discussed on how bacteria use an anode as an electron acceptor and to what extent they generate electrical output. The MFC technology is evaluated relative to current alternatives for energy generation. Electricity generation by direct oxidation of glucose in mediator less microbial fuel cells has been reported in [17]. The internal resistance Rint of a mediator-less microbial fuel cell (MFC) has been determined as a function of cell voltage using electrochemical impedance spectroscopy (EIS) for an MFC with and without Shewanella oneidensis MR-1 [18].

Improved fuel cell and electrode designs for producing electricity from microbial degradation has been suggested [19], a new one-compartment fuel cell was composed of a rubber bunged bottle with a centerinserted anode and a window-mounted cathode containing an internal, proton-permeable porcelain layer. This fuel cell design was less expensive and more practical than the conventional two-compartment system, which requires aeration and a ferricyanide solution in the cathode compartment. Microbial fuel cell in enhancing anaerobic biodegradation of diesel proposed in [20] MFC technology can potentially be applied to enhance subsurface bioremediation of contaminants such as petroleum hydrocarbons by providing an inexhaustible source of terminal electron acceptors to a groundwater environment that is likely depleted in thermodynamically favourable electron acceptors such as oxygen and nitrate. Results indicate that anaerobic biodegradation of diesel range organics (compounds eluting with $\mathrm{n}$-alkane markers ranging in size from C-8 to C-25) was significantly enhanced. A miniature microbial fuel cell operating with an aerobic anode chamber has been successfully designed by [21], MFC is described that utilizes an aerobic culture of Shewanella oneidensis DSP10 as the active electrochemical species in the anode chamber. Findings showed a maximum power of $0.54 \mathrm{~mW}$, which is $37 \%$ drop in power when compared to the anaerobic mediated system.

Unstable power generated via MFC necessitated a work for a continuous electricity production from artificial wastewater using a mediator-less microbial fuel cell in a study reported by [22], An MFC was optimized in terms of MFC design factors and operational parameters for continuous electricity production using artificial wastewater (AW). The performance of MFC shows a significant improvement in the power output and its reliability.

One study [23], focuses on Bio-electrochemical treatment of distillery wastewater in microbial fuel cell facilitating decolourization and desalination along with power generation. MFC was operated at three substrate loading conditions in fed-batch mode under acidophilic (pH 6) condition using anaerobic consortia as anodicbiocatalyst. Current visualized marked improvement with increase in substrate load without any process inhibition (2.12-2.48 mA). An improved microbial fuel cell with laccase as the oxygen reduction catalyst developed by [24], MFCs, generate electrical power through the anodic oxidation of organic substrates mediated by micro-organisms, while the reduction of the electron acceptor (oxidant) occurs at the cathode. Therefore, in the present paper, the experiment will be conducted using wastewater from the groundnut mill as the MFC substrate and the usage of GOME as substrate which contains a mixture of Clostridium sp.and Escherichial Coli. Hence the mediator-less MFC will be employed in the present work.

\section{MATERIALS AND METHODS}

\subsection{Overview}

In the first instance, the miniature MFC system is designed and constructed. Then the experimental works are carried out using our new approach GOME as the MFC substrates. The experiments investigate two different modes of operations; batch process and continuous flow process. Finally, the materials deposited at the anode surface area are analysed using Scanning Electron Microscope (SEM). 


\subsection{Materials Constructions}

A miniature reversible PEM fuel cell from Thames and Kosmos, Newport, RI USA is employed for the fuel cell assemblies. Both anode and cathode are made from stainless steel. The body of the fuel cell is made of polycarbonate. The cathode and anode compartments are separated by means of Proton Exchange Membrane., made of Toray carbon paper and Nafion membrane. The schematic diagram of the MFC is shown in Figure 1. While Figure 2 and 3 shows the photo of the miniature MFC.

\subsection{Dimensions}

The MCF shown in figures 2 and 3 has a dimension of $6.5 \mathrm{~cm}$ in length and $6.5 \mathrm{~cm}$ width. The corresponding dimension for anode and cathode is $3.5 \mathrm{~cm}$ in length and $3.5 \mathrm{~cm}$ in width. This is equivalent to $12,25 \mathrm{~cm}^{2}$ of anode surface. A simple calculation yields

Anode Surface Area $=$ Lenght ${ }^{*}$ Width

\subsection{Experiments}

Initially, both chambers were filled with deionized water and run for 24 hours. Furthermore, the anode feed tank was substituted with GOME and the GOME was pumped to the anode of the MCF for 24 hours, before the potential difference reading is taken. The experiment was conducted at room temperature, assumed to be $27^{\circ} \mathrm{C}$. After that, two experiments were conducted. The first experiment is for batch-fed MFC and the subsequent experiment is for continuous flow MFC.

\subsection{Dimensions}

The MCF shown in figures 2 and 3 has a dimension of $6.5 \mathrm{~cm}$ in length and $6.5 \mathrm{~cm}$ width. The corresponding dimension for anode and cathode is $3.5 \mathrm{~cm}$ in length and $3.5 \mathrm{~cm}$ in width. This is equivalent to $12,25 \mathrm{~cm}^{2}$ of anode surface. A simple calculation yields

$$
\text { Anode Surface Area }=\text { Lenght } \times \text { Width }
$$

\subsection{Experiments}

Initially, both chambers were filled with deionized water and run for 24 hours. Furthermore, the anode feed tank was substituted with GOME and the GOME was pumped to the anode of the MCF for 24 hours, before the potential difference reading is taken. The experiment was conducted at room temperature, assumed to be $27^{\circ} \mathrm{C}$. After that, two experiments were conducted. The first experiment is for batch-fed MFC and the subsequent experiment is for continuous flow MFC.
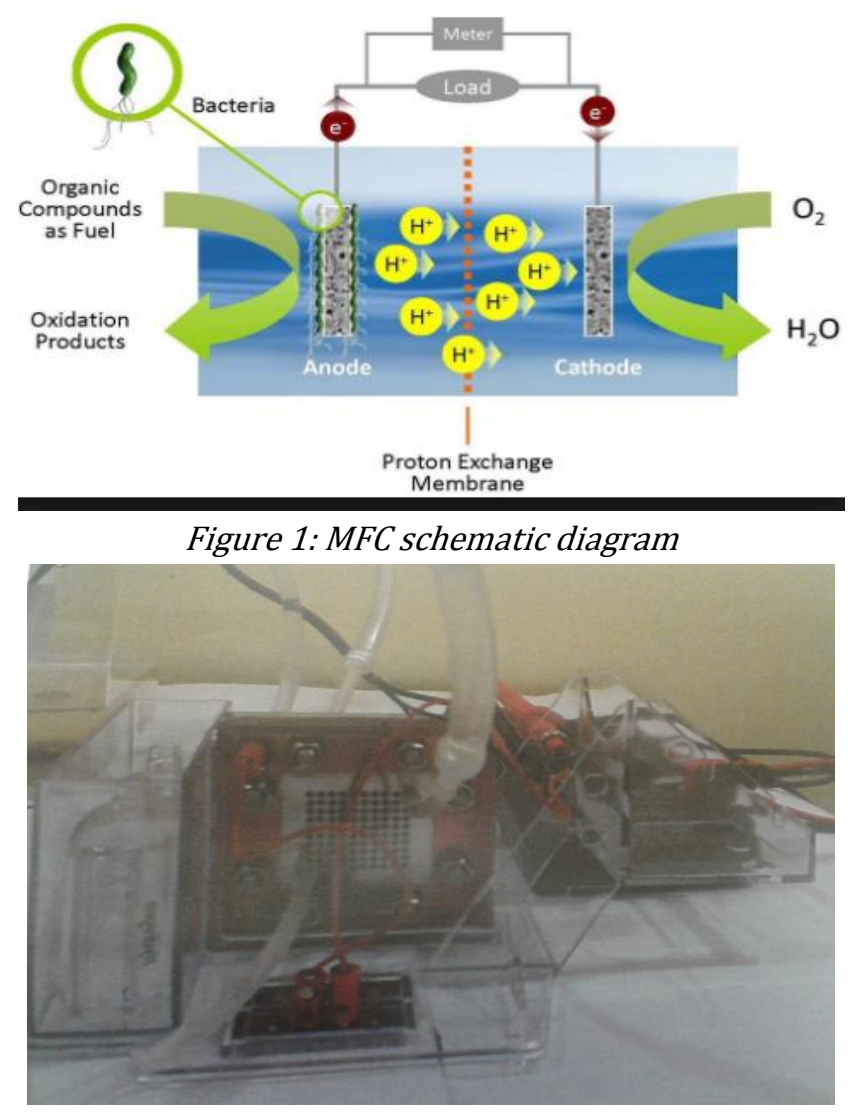

Figure 2: MFC side view

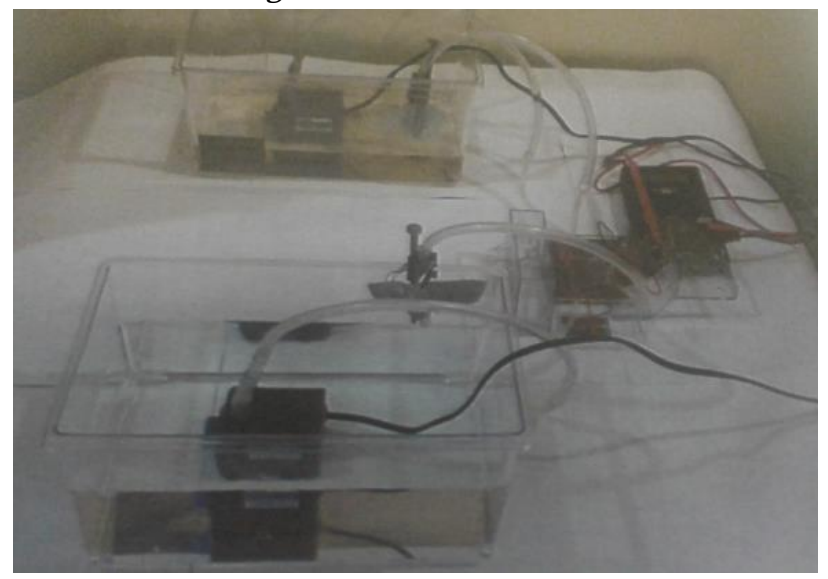

Figure 3: Overall MCF system

\subsection{Measurement of Cell Potential and Power Density}

The overall performance of the developed MFC is judged based on the power output and Columbic efficiency. Power is computed as follows:

$$
P=I \times E_{C E L L}
$$

The voltage is measured across a fixed external resistor ( $R_{E X T}$ ), while the current is obtained using ohms law equations:

$$
I=\frac{E_{C E L L}}{R_{E X T}}
$$

Thus, the power is conveniently calculated using eqn. 4 . 


$$
P=\frac{E_{C E L L}^{2}}{A_{A N} \times R_{E X T}}
$$

The power output is usually normalized to the projected anode surface because the anode is where the biological reaction is taking place. The power density shows the amount of power per unit area in the anode $\left(P_{a N}, W / m^{2}\right)$ is therefore calculated on the basis of the area of the anode $\left(\mathrm{A}_{\mathrm{AN}}\right)$. In this work, the cell potential was measured using Kosmos RE830B Multi-meter at the interval of 30 minutes. The measured potential was then converted to power density using Equation 4.

\subsection{Surface Area Deposition}

The surface area for both anode and cathode electrodes were examined using Scanning Electron Microscope (SEM) by JOEL JSM-6701f, Japan. The surface area condition photos were taken and the biofilm formed at the surface is collected and observed using SEM.

\section{RESULTS AND DISCUSSION}

When operating the MFC control system using deionized water, it was observed that continuous flow process resulted in higher cell potential compared to

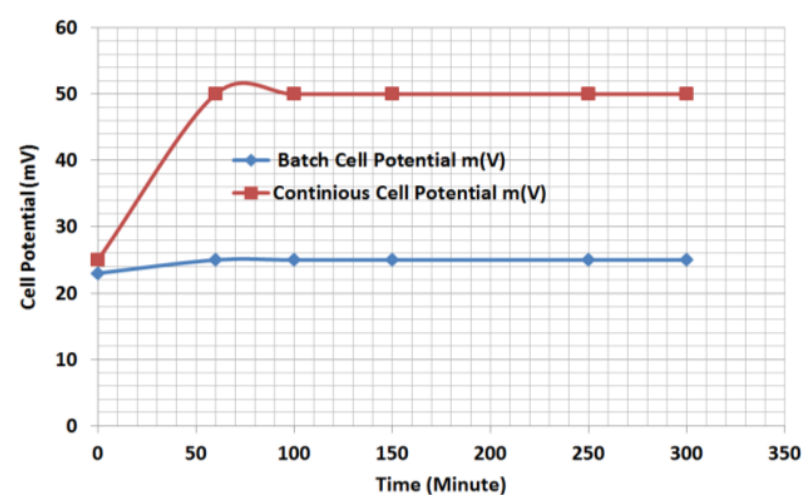

Figure 4: Cell potential obtained by using MFC control

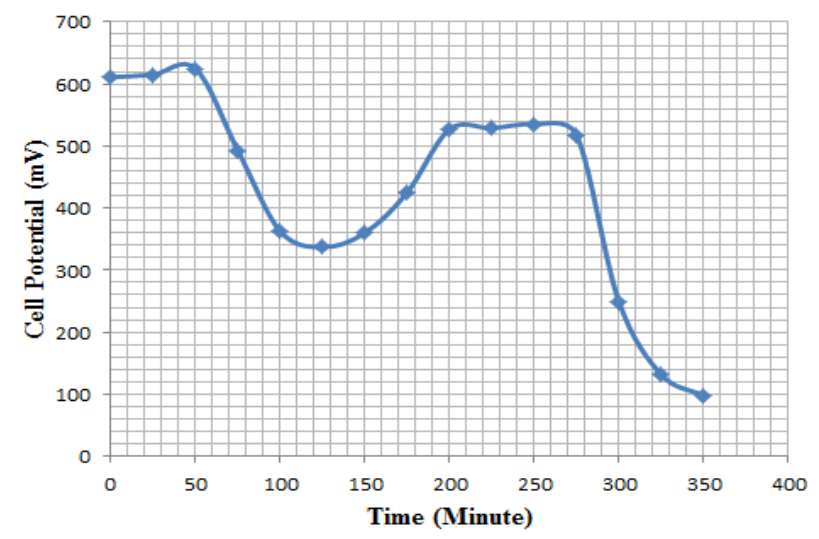

Figure 6: Cell potential obtained by using continuous process at low feed rate batch process. The voltages attained are $52 \mathrm{mV}$ and 21 $\mathrm{mV}$ respectively. Figure 4 shows the cell potential obtained using the MFC control. Both voltages reading were decreasing rapidly. This shows that a capacitance attribute associated with the deionized water used to inoculate the MFC, similar findings was reported by [25].

In the second experiment, the MFC system is operated at batch process using GOME as substrate. The feed is pumped at a low rate (400 litre/hour) to the anode chamber. The system yields a maximum voltage of 363 $\mathrm{mV}$ which is $\left(54 \mathrm{~mW} / \mathrm{m}^{2}\right)$. The cell potential readings are depicted in Figure 5. In the third experiment, the MFC is operated at continuous mode process. Firstly, the feed is pumped into the MFC system at a low feed rate (400 litre/hour). Figure 6 shows the cell potential reading and the maximum voltage attained is $625 \mathrm{mV}$ $\left(160 \mathrm{~mW} / \mathrm{m}^{2}\right)$. When the feed rate was increased to 420 litre/hour, a higher voltage is obtained as shown in Figure 7, the MFC yielded energy of about $727 \mathrm{mV}$ (217 $\mathrm{mW} / \mathrm{m}^{2}$ ). It is noted that the continuous flow yielded higher voltage compared with the batch process. This strongly indicates that the higher the feed rate the more energy will be obtained.

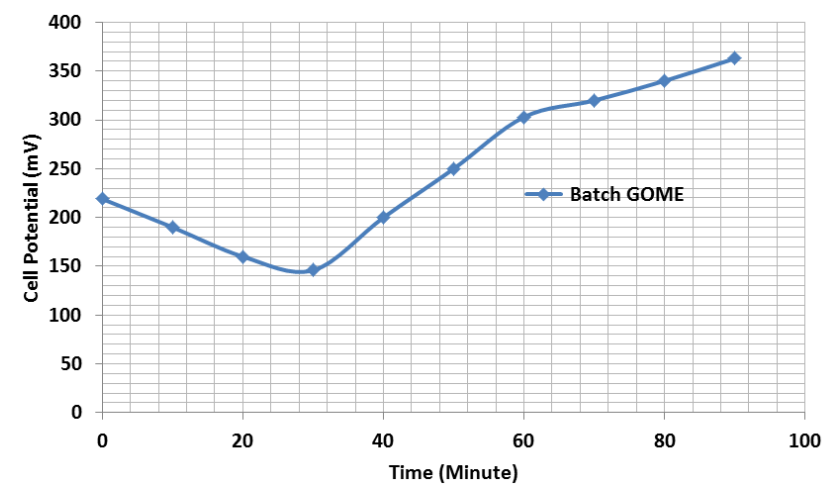

Figure 5: Cell potential obtained by using batch process

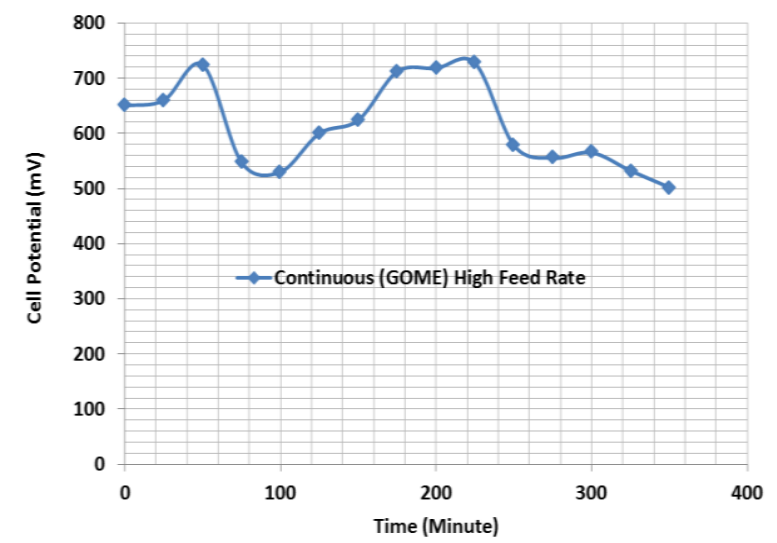

Figure 7: Cell potential obtained by using continuous process at high feed rate 


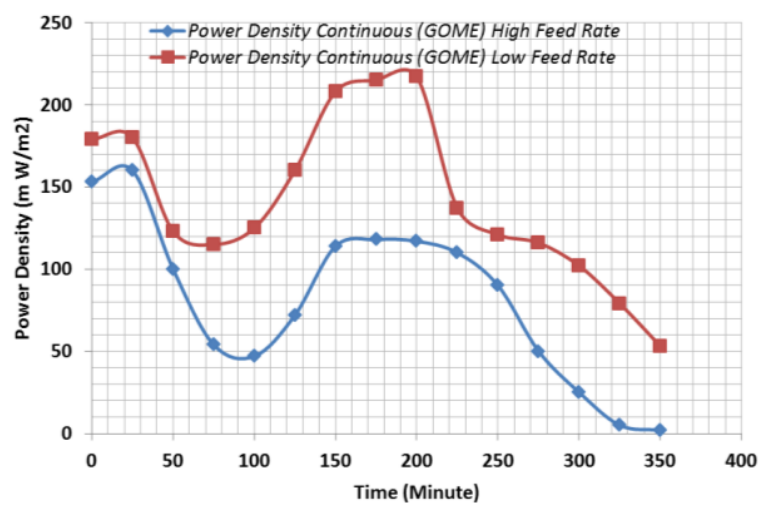

Figure 8: Power density obtained at different feed rate

The cell potential readings were converted to power density using the desired equation stated in the methodology section (Equation 4). The comparison of the power density in the third experiments using low feed rate and high feed rate is depicted in Figure 8. The purpose of doing this is to see the clear difference when the substrate is increased or decreases, for better understanding of the developed system. The maximum power density achieved using the low feed rate $(400$ litre/hour) is $160 \mathrm{~mW} / \mathrm{m}^{2}$, while the highest power density obtained at high feed rate (420 litre/hour) is $217217 \mathrm{~mW} / \mathrm{m}^{2}$.

Upon completion of the experiment, the MFC is disassembled to observe the state condition of anode and cathode surface area. It was found that there are deposition appeared on the surface area of the anode, but no deposition found in the surface area of the cathode as expected see Figure 9 and 10. The deposition forms a biofilm and this biofilm is separated from the electrode by vortexing. The biofilm was then analysed using SEM JEOL JSM-670IF. Thus, SEM observation confirmed the existence of small particles on the surface of the anode as shown in Figure 11.

\subsection{Discussion}

This research shows the potential of using GOME substrate in an MFS. The experimental results affirmed that GOME could be used to yield a substantial power density of $217 \mathrm{~mW} / \mathrm{m}^{2}$ than previous studies using mixed culture $\left(146 \mathrm{~mW} / \mathrm{m}^{2}\right)$ [26]. This could probably be as a result of using high content of degradable organic matter GOME. The power generated based on batch-feed system is lower than that of continuous system. This might be as a result of insufficient time given to the substrate to undergo anaerobic reaction prior to taking of measurement. Hence, continuous system is preferable method when compared with the batch-fed system. Similar findings was reported by [12]. The higher power density observed in the higher

Nigerian Journal of Technology feed rate demonstrates that the higher feed rate allows more composition of wastewater samples collected in the anode chamber. The results support the findings of [12].

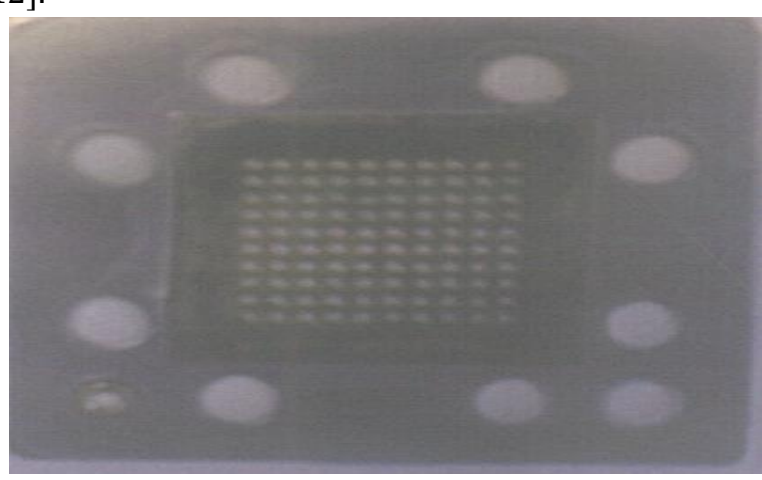

Figure 9: Biofilm formed at anode surface area

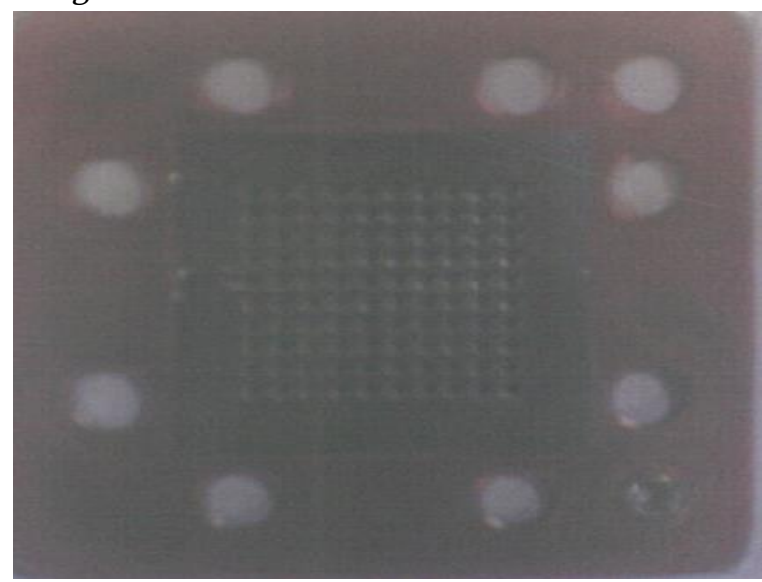

Figure 10: Biofilm formed at cathode surface area

It is also noted that the cell potential reading is reducing over time. This could probably be due to the development of biofilm in the anode surface area. The biofilm development will decrease the area of microbial activity. Hence, this slows down the process of oxidising the substrate energy. The development of the biofilm must be taken into consideration in future works to upscale the MFC regular maintenance and cleaning the anode surface regularly. The MFC is likely to be cleaner technology for the generation of useful energy with zero carbon emission, as the MFC does not emit any gas that is harmful to the environment as the by-products produced are carbon dioxide and water. The use of pump with internal filter is necessary in the operation of MFC. The sediment from the POME is likely to cause fouling and degradation to the proton exchange membrane in the MFC. Though, there are many limitations that worth nothing in this research work, other similar research work conducted using diverse approach have reported power density yield below $30 \mathrm{~mW} / \mathrm{m}^{2}[12,24]$, while some works result showed power density above $90 \mathrm{~mW} / \mathrm{m}^{2}[10,17]$.

Vol. 37, No. 4, October, 2018 


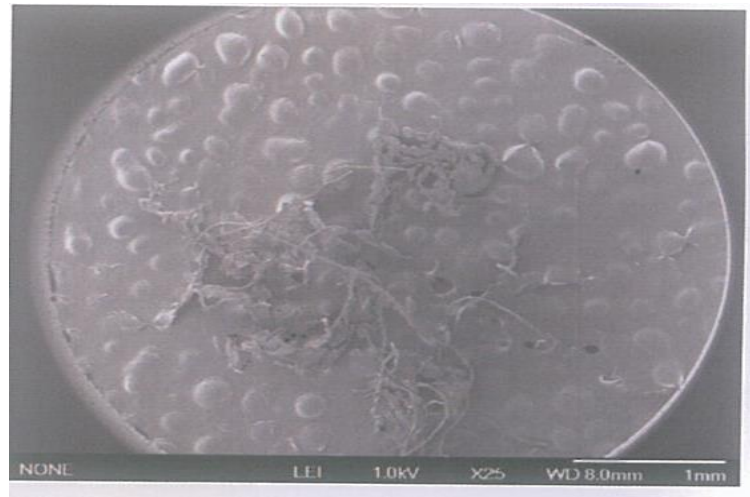

(a)

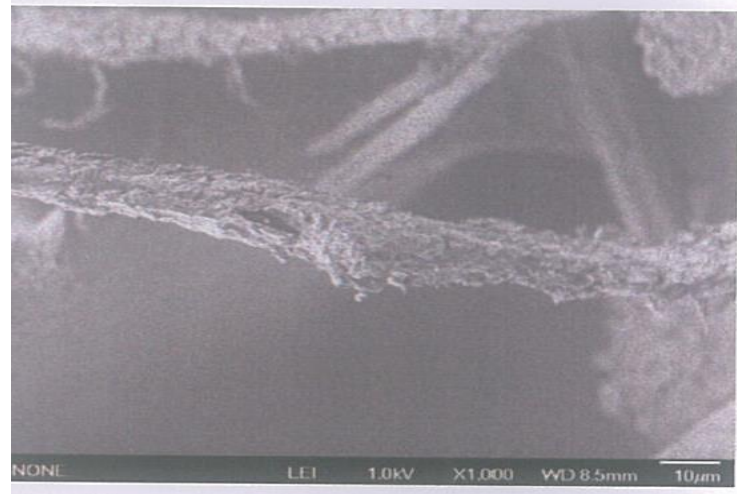

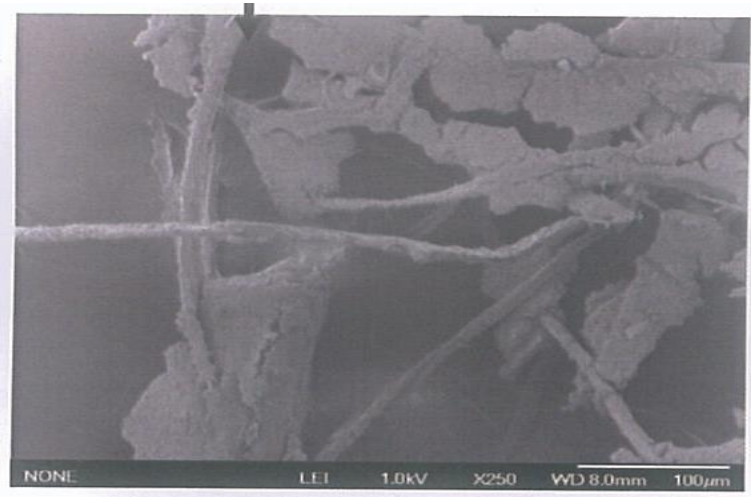

(b)

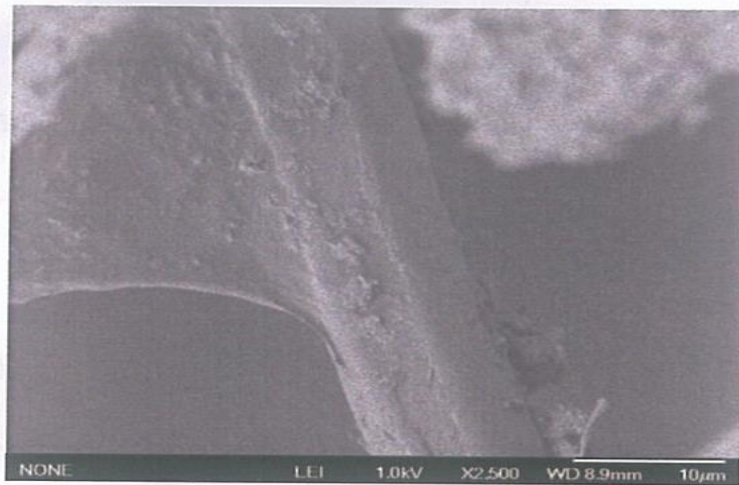

Figure 10: Biofilm formed at anode surface area with magnification (a) x25 (b) x250 (c) $\times 1,000(d) \times 2,500$

The MFC may provide a suitable energy in the near future as Nigeria policy on agriculture currently is receiving attention by the government. It is very likely to place MFC on-site at the groundnut oil small scale mill to generate electricity for their commercial activities or to export energy to the grid.

\section{CONCLUSION AND RECOMMENDATION}

Based on the experimental works, it can be concluded that GOME is a potential substrate that can be used to generate electricity from the MFC. This is due to fact that GOME is rich in organic matter. This organic matter is oxidized by microorganisms readily in the effluent. The process release electron from the anode to cathode and by conventional way, electrical current is produced vice versa. The maximum voltage attained from the current MFC system is $625 \mathrm{mV}\left(160 \mathrm{~m} \mathrm{~W} / \mathrm{m}^{2}\right)$. The amount of voltage attained in the MFC system depends on the feed rate of the substrate to each chamber. The study shows that the higher feed rate resulted in high voltage unlike low feed rate, which resulted in a low voltage. The study results are in line with previous findings as demonstrated based on results comparison. For the transient performance, it was observed that after achieving the maximum voltage, the voltage reading decrease with time. Though, the voltage attained in this work is low, this is due to the fact that the current MFC is depends on GOME to produce electricity. Though, the present study targeted to show the potential of using GOME to produce electricity, an improvement is required in the MFC design, a miniature fuel cell is used to perform the experiment. This provides a small area for microbial activity. Other effluents may be considered in future works for system improvements

\section{ACKNOWLEDGMENTS}

This project has been made possible as a result of cooperation and support rendered by many organizations. Special thanks to the Centre for Renewable Energy and Climate Change (CERECC) who partially financed the work under initial research funds on renewable energy.

\section{REFERENCES}

[1] S. Lawan, W. Abidin, T. Masri, W. Chai, and A. Baharun, "Wind power generation via ground wind station and topographical feedforward neural network (T-FFNN) model for small-scale applications," Journal of cleaner production, vol. 143, pp. 1246-1259, 2017.

Vol. 37, No. 4, October, 2018 
[2] S.-Y. Lee and S.-J. Park, "A review on solid adsorbents for carbon dioxide capture, "Journal of Industrial and Engineering Chemistry, vol. 23, pp. 1-11, 2015.

[3] A. S. Aliyu, J. O. Dada, and I. K. Adam, "Current status and future prospects of renewable energy in Nigeria," Renewable and sustainable energy reviews, vol. 48, pp. 336-346, 2015.

[4] M. Shaaban and J. Petinrin, "Renewable energy potentials in Nigeria: meeting rural energy needs," Renewable and Sustainable Energy Reviews, vol. 29, pp. 72-84, 2014

[5] S. Jekayinfa and O. Omisakin, "The energy potentials of some agricultural wastes as local fuel materials in Nigeria," 2005.

[6] S. Idris, Y. Iyaka, B. Dauda, M. Ndamitso, and M. Umar, "Kinetic study of utilizing groundnut shell as an adsorbent in removing chromium and nickel from dye effluent," Am Chem Sci J, vol. 2, pp. 1224, 2012.

[7] S. Peighambardoust, S. Rowshanzamir, and M. Amjadi, "Review of the proton exchange membranes for fuel cell applications," International journal of hydrogen energy, vol. 35 , pp. 9349-9384, 2010.

[8] X. Cheng, Z. Shi, N. Glass, L. Zhang, J. Zhang, D. Song, et al., "A review of PEM hydrogen fuel cell contamination: Impacts, mechanisms, and mitigation," Journal of Power Sources, vol. 165, pp. 739-756, 2007.

[9] N. Mahato, A. Banerjee, A. Gupta, S. Omar, and K. Balani, "Progress in material selection for solid oxide fuel cell technology: A review," Progress in Materials Science, vol. 72, pp. 141-337, 2015.

[10] B. Min and B. E. Logan, "Continuous electricity generation from domestic wastewater and organic substrates in a flat plate microbial fuel cell," Environmental Science \& Technology, vol. 38, pp. 5809-5814, 2004.

[11] H. Liu and B. E. Logan, "Electricity generation using an air-cathode single chamber microbial fuel cell in the presence and absence of a proton exchange membrane," Environmental Science \& Technology, vol. 38, pp. 4040-4046, 2004.

[12] B. Min, J. Kim, S. Oh, J. M. Regan, and B. E. Logan, "Electricity generation from swine wastewater using microbial fuel cells," Water Research, vol. 39, pp. 4961-4968, 2005.

[13] Y. Feng, X. Wang, B. E. Logan, and H. Lee, "Brewery wastewater treatment using air-cathode microbial fuel cells," Applied Microbiology and Biotechnology, vol. 78, pp. 873-880, 2008.

[14] J. Heilmann and B. E. Logan, "Production of electricity from proteins using a microbial fuel cell," Water Environment Research, vol. 78, pp. 531-537, 2006.

[15] P. L. McCarty, J. Bae, and J. Kim, "Domestic wastewater treatment as a net energy producercan this be achieved?," ed: ACS Publications, 2011.

[16] K. Rabaey and W. Verstraete, "Microbial fuel cells: novel biotechnology for energy generation," TRENDS in Biotechnology, vol. 23, pp. 291-298, 2005.

[17] A. E. Franks and K. P. Nevin, "Microbial fuel cells, a current review," Energies, vol. 3, pp. 899-919, 2010.

[18] S. K. Chaudhuri and D. R. Lovley, "Electricity generation by direct oxidation of glucose in mediatorless microbial fuel cells," Nature biotechnology, vol. 21, p. 1229, 2003.

[19] D. H. Park and J. G. Zeikus, "Improved fuel cell and electrode designs for producing electricity from microbial degradation," Biotechnology and bioengineering, vol. 81, pp. 348-355, 2003.

[20] J. M. Morris, S. Jin, B. Crimi, and A. Pruden, "Microbial fuel cell in enhancing anaerobic biodegradation of diesel," Chemical Engineering Journal, vol. 146, pp. 161-167, 2009.

[21] B. R. Ringeisen, R. Ray, and B. Little, "A miniature microbial fuel cell operating with an aerobic anode chamber," Journal of Power Sources, vol. 165, pp. 591-597, 2007.

[22] H. Moon, I. S. Chang, and B. H. Kim, "Continuous electricity production from artificial wastewater using a mediator-less microbial fuel cell," Bioresource Technology, vol. 97, pp. 621-627, 2006.

[23] G. Mohanakrishna, S. V. Mohan, and P. Sarma, "Bio-electrochemical treatment of distillery wastewater in microbial fuel cell facilitating decolorization and desalination along with power generation," Journal of Hazardous Materials, vol. 177, pp. 487-494, 2010.

[24] 0. Schaetzle, F. Barrière, and U. Schröder, "An improved microbial fuel cell with laccase as the oxygen reduction catalyst," Energy \& Environmental Science, vol. 2, pp. 96-99, 2009.

[25] P. Justin and G. R. Rao, "CoS spheres for high-rate electrochemical capacitive energy storage application," International Journal of Hydrogen Energy, vol. 35, pp. 9709-9715, 2010.

[26] Z. Ren, T. E. Ward, and J. M. Regan, "Electricity production from cellulose in a microbial fuel cell using a defined binary culture," Environmental Science \& Technology, vol. 41, pp. 4781-4786, 2007. 